\title{
TRADYCYJNA TEORIA OPTYMALNYCH OBSZARÓW WALUTOWYCH
}

\section{WPROWADZENIE}

Artykuł wyróżnia zastosowanie sformalizowanej perspektywy metodologicznej. Celem artykułu jest przedstawienie i ocena założeń tradycyjnej ${ }^{1}$ teorii optymalnych obszarów walutowych (TOOW) metodą idealizacji i konkretyzacji w rozumieniu Leszka Nowaka². Szczególną uwagę poświęcono kryteriom optymalności. W artykule przyjęto podejście historyczne, tj. analizę ewolucji wyjściowej koncepcji optymalnych obszarów walutowych (OOW). Zastosowano analizę porównawczą i wykorzystano koncepcję idealizacji i konkretyzacji³, która pozwoliła zidentyfikować w poszczególnych modelach optymalnych obszarów walutowych cele, czynniki główne i uboczne oraz umożliwiła ocenę charakteru i spójności założeń. W pierwszej części artykułu wyjaśniono przyczynę wyboru koncepcji idealizacji i konkretyzacji jako narzędzia badawczego oraz przyjęte w niej założenia metodologiczne. W następnej części zaprezentowano zbiór wyjściowych założeń teoretycznych optymalnych obszarów walutowych. W kolejnych częściach $\mathrm{w}$ ślad za literaturą przedmiotu ${ }^{4}$ wyróżniono okresy, w których dominowały zbliżone stanowiska badawcze wobec pierwotnych podstaw teoretycznych. W każdej części przeanalizowano z osobna reprezentatywne modele, stosując podejście metodologiczne idealizacji i konkretyzacji ${ }^{5}$. Artykuł zamyka podsumowanie.

${ }^{1}$ G. Tchorek, Teoretyczne podstawy integracji walutowej, w: P. Kowalewski, G. Tchorek, J. Górski (red.), Mechanizmy funkcjonowania strefy euro, Narodowy Bank Polski, WoltersKluwer Polska, Warszawa 2010, s. 46-52 oraz G. Tavlas, The "New" Theory of Optimum Currency Area, Blackwell, Cambridge 1993.

${ }^{2}$ L. Nowak, Wstep do idealizacyjnej teorii nauki, PWN, Warszawa 1977.

${ }^{3}$ Ibidem.

${ }^{4}$ H. Dellas, G. Tavlas, An Optimum-Currency-Area Odyssey, Working Paper no. 102, Bank of Greece, Athens 2009; F. P. Mongelli, European Economic and Monetary Integration and the Optimum Currency Area Theory, European Commission Directorate-General for Economic and Financial Affairs, Brussels 2008; idem, What is European Economic and Monetary Union Telling us about the Properties of Optimum Currency Areas?, „Journal of Common Market Studies” 43, 2005, nr 3; idem, "New" Views on the Optimum Currency Area Theory: What is EMU Telling Us?, ECN Working Paper no. 138, Frankfurt 2002.

${ }^{5}$ L. Nowak, op. cit. 


\section{WPROWADZENIE METODOLOGICZNE}

W poniższym artykule w celu przedstawienia ewolucji teorii optymalnych obszarów walutowych wykorzystano metodę idealizacji i konkretyzacji w rozumieniu Nowaka ${ }^{6}$ oraz dedukcję. Wybór metody analizy był podyktowany obecnym stanem literatury przedmiotu, która jest bardzo liczna, obszerna i w wielu kwestiach niespójna co do klasyfikacji kryteriów optymalności ${ }^{7}$. Podejście wypracowane przez Nowaka pozwala na wyodrębnienie głównych elementów modeli i na spójną ocenę ewolucji TOOW.

Publikację pierwszych artykułów dotyczących TOOW datuje się na początek lat sześćdziesiątych ubiegłego wieku. Od początku TOOW wzbudzała żywe zainteresowanie i kontrowersje z uwagi na przyjmowane założenia i ich adekwatność do warunków realnej gospodarki ${ }^{8}$. Głównym celem TOOW jest określenie i ocena warunków, które powinny zostać spełnione przez gospodarkę dążącą do włączenia w obszar walutowy, a następnie możliwość badania reakcji na zewnętrzne wstrząsy. Te warunki TOOW określa się mianem kryteriów optymalności ${ }^{9}$, których to ewolucja będzie głównym przedmiotem tego artykułu. W myśl TOOW spełnienie przez gospodarki tych warunków zapewnia optymalność uczestnictwa w obszarze walutowym, tj. pozytywny bilans korzyści i kosztów ${ }^{10}$.

Dotychczasowy dorobek literatury przedmiotu można podzielić, ze względu na cel prac, na dwie grupy:

- weryfikacja wkładu i wpływu wybranych kryteriów optymalności (wśród najważniejszych twórców teorii należy wyróżnić prace Mundella, McKinnona, Kenena, Frankela i Rose, Fleminga i innych $\left.{ }^{11}\right)$;

${ }^{6} \mathrm{Na}$ potrzeby poniższego artykułu wykorzystano główne założenia jego metodologii, zob. L. Nowak, op. cit.

7 M. Jurek, Międzynarodowy system walutowy $i$ systemy kursowe $w$ warunkach integracji finansowej, Wyd. UEP, Poznań 2011.

${ }^{8}$ P. Krugman, Revenge of the Optimum Currency Area, Chicago 2012; G. Tavlas, OptimumCurrency-Area Paradoxes, „Review of International Economics” 17(3), 2009; J. Priewe, Reconsidering the Theories of Optimum Currency Area - A Critique, European Integration in Crisis, Marburg/Lahn, Metropolis 2007; European Commission, One Market, One Money. An Evaluation of the Potential Benefits and Costs of Forming an Economic and Monetary Union, No. 44, Directorate-General for Economic and Financial Affairs, Brussels 1990; Y. Ishiyama, The Theory of Optimum Currency Areas: A Survey, „Staff Papers - International Monetary Fund” 22 , 1975 , nr 2.

9 Anglojęzyczna literatura przedmiotu korzysta zamiennie z określeń: preconditions, prerequisites, criterias, atributes, characteristics, propertie oraz determinants. Polskie określenie kryteria optymalności pochodzi na przykład z G. Tchorek, op. cit. oraz K. Sum, Przystapienie Polski do strefy euro $w$ świetle analizy porównawczej procesów integracji walutowej $w$ Polsce i Hiszpanii, rozprawa doktorska (maszynopis), SGH, Warszawa 2009.

10 Szczegółowe wyjaśnienie założeń TOOW, zob. pkt III.

${ }_{11}$ R. A. Mundell, A Theory of Optimum Currency Areas, „The American Economic Review” 51, 1962, nr 4; R. I. McKinnon, Optimum Currency Areas, „The American Economic Review” 53, 1963, nr 4; P. B. Kenen, What We Can Learn from the Theory of Optimum Currency Areas, HM Treasury, 2002; J. A. Frankel, A. K. Rose, The Endogeneity of the Optimum Currency Area Criteria, 
- porządkowanie, analiza i ocena zbioru kryteriów optymalności (spośród publikacji wyróżnia się prace Mongellego i Tavlasa).

W mniej licznych publikacjach tej drugiej grupy, zwłaszcza polskich ${ }^{12}$, uporządkowano i oceniono założenia teoretyczne za pomocą metody analizy porównawczej z podejściem historycznym. Poniższe rozważania będą wynikały zarówno z podejścia historycznego, jak i logiki metody idealizacji i konkretyzacji. Zatem wyżej wspomniane kryteria optymalności zostały przeanalizowane przy uwzględnieniu przedziałów czasu, które można wyróżnić ze względu na różne podejście do istotności kryteriów oraz logiki idealizacji i konkretyzacji. Przyjęcie perspektywy metodologicznej Nowaka pozwala uwypuklić strukturę i ewolucje TOOW, będącą pod wpływem rywalizacji orientacji teoretycznych, i wykazać korespondencję bazową lub pochodną ${ }^{13}$, co zostało omówione w kolejnych częściach artykułu.

W myśl perspektywy metodologicznej Nowaka przyjęto, że celem badania jest określenie zestawu cech, które powinna posiadać ${ }^{14}$ grupa gospodarek, aby tworzyć optymalny obszar walutowy. Zatem zgodnie z nomenklatura metodologiczną przyjmuje się następujące zmienne ${ }^{15}$ :

$F$ - cecha, badany czynnik określany jest jako pozytywny bilans korzyści i kosztów przystapienia danej gospodarki do obszaru walutowego, tj. optymalność obszaru walutowego dla gospodarek w nim uczestniczacych,

$Z$ - zakres, zbiór podmiotów, które posiadają cechę $F$, tj. grupa gospodarek utożsamiana z grupą państw należących lub kandydujących do OOW,

$Z=U-$ przyjmuje się dla celów badawczych, że uniwersum równe jest zakresowi, więc analizie podlegają wszystkie państwa posiadające tę cechę,

Czynniki istotne - wszystkie czynniki, które wpływają na optymalność obszaru walutowego, czyli kryteria optymalności,

Czynnik główny - kryterium optymalności, którego spełnienie jest niezbędne do pozytywnego bilansu korzyści i kosztów obszaru walutowego,

Czynnik poboczny - kryterium optymalności, które jest istotne w mniejszym stopniu niż czynnik główny,

Czynnik ślepy - kryterium optymalności nieistotne dla czynnika określanego,

$P_{F}^{Z}$ - przestrzeń czynników istotnych dla optymalności obszaru walutowego stanowi grupa kryteriów optymalności,

$O^{Z}\left(P_{F}^{Z}\right)$ - obraz czynników istotnych, założono, iż $P_{F}^{Z}$ stanowi podzbiór obrazu przestrzeni czynników istotnych (badacze wykazali zbiór wszystkich faktycznie istotnych kryteriów, ale możliwe, że występują jeszcze inne kryteria, których dotychczasowa literatura nie zbadała),

„The Economic Journal” 108, nr 449, Blackwell, Malden 1998; J. M. Fleming, On Exchange Rate Unification, „The Economic Journal” 81, 1971, nr 323.

${ }_{12}$ Kompleksowa polska analiza logiczna założeń OOW przedstawiona została w: G. Tchorek, op. cit.

${ }^{13}$ Zob. L. Nowak, op. cit., s. 188-195.

${ }^{14}$ Innymi słowy, kryteriów, które powinna spełnić.

${ }^{15}$ L. Nowak, op. cit., s. 42-45. 
$O^{U}\left(S_{F}^{Z}\right)$ - obraz struktury esencjalnej to hierarchiczny rozkład kryteriów optymalności względem ich istotności, który różni się dla każdego z wyróżnionych okresów.

Wykazane czynniki główne oraz poboczne były przedmiotem formułowania prostego prawa idealizacyjnego, konkretyzacji oraz twierdzenia faktualnego ${ }^{16}$.

\section{PODSTAWA TEORETYCZNA}

Tradycyjna TOOW dominowała w literaturze przedmiotu do początku lat dziewięćdziesiątych XX w. ${ }^{17}$ Powstała w latach sześćdziesiątych poprzedniego stulecia w rezultacie dyskusji nad wykorzystywanym wówczas systemem z Bretton Woods oraz porównań modelu gospodarki europejskiej i amerykańskiej. Jednym z ważniejszych zadań ówczesnych badaczy było zdefiniowanie narzędzia absorbującego lub zmniejszającego podatność gospodarki (lub grupy gospodarek) na nagłe wstrzasy ekonomiczne, dotykające gospodarki z nierównomierną siła, tj. wstrząsy asymetryczne. W niniejszej pracy przyjmuje się definicję wstrząsu asymetrycznego jako „nieoczekiwanej zmiany łącznego popytu i (lub) podaży, która uderza jeden kraj, ale nie jego partnerów handlowych"18. Przedmiotem debaty ${ }^{19}$ był przede wszystkim wybór pomiędzy płynnymi a usztywnionymi kursami walutowymi (ang. pegged lub fixed exchange rates).

Do najważniejszych twórców TOOW, czyli autorów artykułów, które wywołały powszechną dyskusję na łamach czasopism naukowych, zaliczyć należy Roberta Mundella, Ronalda McKinnona oraz Petera Kenena ${ }^{20}$. Publikacje Mundella, McKinnona i Kenena zapoczątkowały debatę na temat potencjalnych korzyści z usztywnienia kursów wymiany i tworzenia obszarów walutowych. Artykuł Mundella, opublikowany w 1961 r., stanowił alternatywę ${ }^{21}$

${ }^{16}$ L. Nowak, op. cit., s. 81-85.

${ }^{17}$ F. P. Mongelli, What Is European Economic...; idem, „New” Views...; G. Tavlas, op. cit. Por. K. Sum, op. cit.

${ }^{18}$ O. Blanchard, Makroekonomia, Wolters Kluwer Polska, Warszawa 2011, s. 981.

${ }^{19}$ Por. R. Mundell, op. cit.

${ }^{20}$ A. Artner, P. Rona, Euros(c)eptic - The Theory of the Optimum Currency, Area and the Practice of the Euro, „Romanian Journal of European Affairs” 12, 2012, nr 2; P. De Grauwe, The Economics of Monetary Integration, wyd. 9, OUP, Hampshire 2012; M. Jurek, op. cit.; G. Tavlas, op. cit.; H. Dellas, G. Tavlas, op. cit.; G. Corsetti, A Modern Reconsideration of the Theory of Optimal Currency Areas, European Commission Directorate-General for Economic and Financial Affairs Publications, Brussels 2008; F. P. Mongelli, op. cit.; J. R. Colthoff, Sector Specialization in the EMU-countries: Is There a Euro-effect?, Univ. of Amsterdam Faculty of Economics and Econometrics Department of Economics Working Paper, 2007; T. W. Kolasiński, Geneza i process tworzenia Unii Gospodarczej i Walutowej w Europie Zachodniej, w: A. Z. Nowak, A. Stępniak (red.), Strefa euro - wyzwanie dla Polski, Wyd. Naukowe Wydziału Zarządzania UW, Warszawa 2003; T. Bayoumi i, B. Eichengreen, Ever Closer to Heaven? An Optimum-Currency-Area Index for European Countries, Center for International and Development Economics Research, Institute of Business and Economic Research, UC Press, Berkeley 1996.

${ }^{21}$ A. Artner i P. Rona zwracają uwagę, że równocześnie w tym samym roku ukazała się inna praca o zbliżonej tematyce, co artykuł Roberta Mundella, autorstwa Beli Ballassy. 
dla stanowisk prezentowanych na rzecz płynnych kursów walutowych (ang. flexible exchange rates) przez m.in. Miltona Friedmana z 1953 r., Jamesa Meade’a z 1957 r. ${ }^{22}$ Zakładano bowiem, że kurs wymiany waluty może posłużyć jako skuteczne narzędzie regulacji i stabilizacji gospodarki. Usztywnienie kursu walutowego było postrzegane jako utrata ważnego instrumentu polityki pieniężnej i kursowejej.

W niniejszym artykule za obszar walutowy uznaje się ${ }^{24}$ „geograficzny obszar jednoczący kraje lub regiony, w ramach którego obowiązuje jedna wspólna waluta lub kilka walut, a kursy ich wymiany sa nieodwracalnie usztywnione i dąży się do ich połączenia w jedną walutę. Kurs wymiany wspólnej waluty może być natomiast płynny w stosunku do walut krajów spoza obszaru”. Jak podkreślił George Tavlas ${ }^{25}$, ze względu na model trójkąta niemożliwości Padoa-Schioppa obszar walutowy w literaturze przedmiotu jest utożsamiany $\mathrm{z}$ integracją monetarną ${ }^{26}$, która zakłada, poza usztywnionymi nieodwracalnie kursami walutowymi, integrację rynku finansowego, liberalizację przepływów kapitału i wspólną politykę monetarną. Unifikacja monetarna jest kolejnym etapem, który zakłada wspólną walutę i jeden bank centralny.

Za literatura przedmiotu przez pojęcie optymalności obszaru walutowego rozumie się spełnienie kryteriów optymalności, czyli czynników, przy założeniu jednej wspólnej waluty lub kilku o usztywnionym kursie, które łącznie przynoszą pozytywny bilans korzyści i kosztów członkostwa w obszarze walutowym. Kraje w nim uczestniczące czerpią więcej korzyści, niż gdyby pozostały zbiorem krajów o płynnych względem siebie kursach wymiany waluty ${ }^{27}$. Ponadto realizacja kryteriów optymalności sprzyja zewnętrznej i wewnętrznej równowadze oraz zmniejsza wpływ lub zwiększa absorpcję wstrząsów ${ }^{28}$. Niektórzy autorzy utożsamiają optymalność ze zwiększeniem się dobrobytu ludności zamieszkującej krajej ${ }^{29}$ Z kolei Michael Burda i Charles Wyplosz ${ }^{30}$ podkreślaja, że optymalny obszar walutowy można uznać także za taki, w którym ujednolicenie waluty nie powoduje zmniejszenia się dobrobytu mieszkańców kraju członkowskiego.

22 Dellas i Tavlas, odnosząc się do pracy Cesarna z 2006 r. stwierdzaja, że praca Friedmana stanowiła istotny wkład w model optymalnych obszarów walutowych, który rozwijał Mundell.

${ }^{23}$ G. Tchorek, op. cit.

${ }_{24}$ Za: F. P. Mongelli, What is European Economic..., s. 608.

25 G. Tavlas, The "New" Theory of Optimum..., s. 665.

${ }^{26}$ Por. J. A. Frankel, A. K. Rose, op. cit.; P. De Grauwe, F. P. Mongelli, Endogeneities of Optimum Currency Areas. What Brings Countries Sharing a Single Currency Closer Together?, ECB, Working Paper Series No. 468, Frankfurt 2005. W tych publikacjach obszar walutowy to unia walutowa, tj. obszar jednej wspólnej waluty, który może być utożsamiany z unifikacja monetarna.

27 F. P. Mongelli, What is European Economic..., passim.

${ }^{28}$ G. Tchorek, op. cit.; F. P. Mongelli, What is European Economic..., passim.

${ }_{29}$ H. G. Grubel, The Theory of Optimum Currency Areas, „The Canadian Journal of Economics/ Revue canadienne d'économique" 3, 1971, nr 2.

${ }^{30} \mathrm{Za}$ : K. Biegun, Kryteria optymalnego obszaru walutowego w rozszerzonej Unii Europejskiej, VIII Konferencja Naukowa Młodych Ekonomistów nt. „Unifikacja gospodarek europejskich: szanse i zagrożenia”, Dymaczewo k. Poznania 2003. 
Zatem mając na uwadze powyższe wyjaśnienia oraz stosując podejście metodologiczne Nowaka ${ }^{31}$, podstawę teoretyczną teorii optymalnych obszarów walutowych stanowi dorobek Mundella, McKinnona i Kenena, którzy opracowali trzy różne modele analizujące efekty wstrząsów popytowych dla dwóch gospodarek.

W modelu Mundella ${ }^{32}$ w ujęciu perspektywy metodologicznej Nowaka, przyjmuje się następujaccy obraz struktury esencjalnej (S 1):

\section{Struktura 1}

$$
\begin{aligned}
& O^{U S_{F:}^{Z}} \text { (3) } L, E^{*} \\
& \text { (2) } L, K, E^{*} \\
& \text { (1) } L, K, \text { Reg, } E^{*} \\
& \text { (0) } L, K, \text { Reg, Uni, } E^{*}
\end{aligned}
$$

$L$ - mobilność pracy w ramach obszaru walutowego i brak mobilności poza obszarem,

$K$ - mobilność kapitału w ramach obszaru walutowego i brak mobilności poza obszarem,

$U n i^{33}$ - unifikacja monetarna (bank centralny, jedna waluta lub dążenie do wspólnej waluty) kryterium nie było w dużym stopniu uwzględnianie i analizowane przez badaczy literatury, jednakże wyróżniono je w poniższej pracy, aby ukazać różnice w definicjach obszaru walutowego twórców teorii,

$R e g$ - założenie, że obszar walutowy zrzesza regiony, a niekoniecznie kraje,

$E$ - elastyczność cen i płac, której rola była podkreślana przez Friedmana w 1953 r.,

$E^{*}$ - symbole z gwiazdką oznaczają czynnik ślepy,

$(3), . .,(0)$ - poziomy istotności ${ }^{34}$.

Przyjmując strukturę esencjalną (S 1), prawo idealizacyjne ${ }^{35}$ (3. poziom istotności) można sformułować następująco: Członkostwo w obszarze walutowym będzie korzystne dla gospodarek charakteryzujących się mobilnością pracy pomiędzy nimi, pomimo braku elastyczności cen i płac. Zakłada się bowiem, że $E$ jest czynnikiem ślepym, czyli nie jest istotny dla optymalności obszaru walutowego ${ }^{36}$.

W świetle struktury esencjalnej (S 1) i powyższych uwag można sformułować pierwszą i drugą konkretyzację oraz trzecią konkretyzację, stanowiąca tzw. twierdzenie faktualne ${ }^{37}$.

Pierwsza konkretyzacja (2. poziom istotności): Członkostwo w obszarze walutowym będzie korzystne dla gospodarek charakteryzujących się mobil-

${ }^{31}$ L. Nowak, op. cit., s. 82-84.

${ }^{32}$ R. Mundell, op. cit.

${ }^{33} \mathrm{~W}$ poniższym artykule przyjmuje się również za czynniki kryteria optymalności, które nie są w prosty sposób mierzalne, co stanowi pewną modyfikację metodologii Nowaka. Niemniej jednak metodologię stosuje się jako przyjęty schemat analityczny w celu ewaluacji istotności najważniejszych kryteriów optymalności.

${ }^{34} \mathrm{~W}$ poniższym artykule przyjmuje się skończoną, tę samą liczbę poziomów istotności dla wszystkich trzech modeli.

${ }^{35}$ L. Nowak, op. cit., s. 81.

${ }^{36}$ Model Mundella z 1961 r. opiera się na założeniu, że ceny i płace są sztywne, wobec czego należy szukać alternatywnego kryterium optymalności.

${ }^{37}$ L. Nowak, op. cit., s. 84. 
nością czynników wytwórczych pomiędzy nimi, tj. kapitału oraz w szczególności pracy, pomimo braku elastyczności cen i płac.

Druga konkretyzacja (1. poziom istotności): Członkostwo w obszarze walutowym będzie korzystne dla gospodarek regionalnych, charakteryzujących się mobilnością czynników wytwórczych pomiędzy nimi, tj. kapitału oraz w szczególności pracy, pomimo braku elastyczności cen i płac.

Twierdzenie faktualne (0. poziom istotności): Członkostwo w obszarze walutowym o wspólnej walucie i wspólnym banku centralnym będzie korzystne dla gospodarek regionalnych charakteryzujacych się mobilnością czynników wytwórczych pomiędzy nimi, tj. kapitału oraz w szczególności pracy, pomimo braku elastyczności cen i płac.

Z kolei model McKinnona ${ }^{38}$ wskazuje, że najważniejsza jest otwartość gospodarki oraz wspólna polityka gospodarcza. Model ten stanowi odniesienie do modelu Mundella i tym samym obraz struktury esencjalnej, w myśl perspektywy metodologicznej Nowaka, można przedstawić następująco (S 2):

\section{Struktura 2}

$$
\begin{aligned}
& O^{U S_{F}^{Z}} \text { (3) } O, \text { Uni, Fis } \\
& \text { (2) O, Uni, Fis, Reg } \\
& \text { (1) O, Uni, Fis, Reg, L } \\
& \text { (0) O, Uni, Fis, Reg, L, K }
\end{aligned}
$$

$O$ - otwartość gospodarki, czyli wysoki stosunek dóbr wymienialnych do niewymienialnych w produkcji i konsumpcji,

Fis - integracja fiskalna,

Reg - dla celów analizy w niniejszej pracy kryterium regionalne Mundella uznaje się za tożsame z kryterium McKinnona, czyli wielkości gospodarki, autor ten bowiem uznaje, że im mniejsza gospodarka, tym mniej przydatny staje się kurs walutowy jako narzędzie stabilizacyjne,

$L$ - McKinnon uznaje, że Mundell, jako kryterium mobilności pracy, rozumiał mobilność geograficzna, niekoniecznie międzysektorowa. Autor ten wskazuje, że otwartość gospodarki sprzyja międzysektorowej mobilności pracy i powinna być zbilansowana z geograficzną mobilnościa pracy. Niemniej jednak w wyniku integracji walutowej mobilność geograficzna może się zwiększyć ex post, co skutkuje obniżeniem poziomu istotność czynnika mobilności pracy, $(3), . .,(0)$ - poziomy istotności.

W świetle powyższych ustaleń dla modelu McKinnona można sformułować następujące prawo idealizacyjne (3.), opierając się na obrazie struktury esencjalnej McKinnona (S 2): Członkostwo w obszarze walutowym o wspólnej walucie, wspólnym banku centralnym i wspólnej polityce monetarnej i fiskalnej będzie korzystne dla otwartych gospodarek.

Na podstawie powyższych rozważań można sformułować pierwszą i drugą konkretyzację oraz twierdzenie faktualne o następującym brzmieniu:

Pierwsza konkretyzacja (2): Członkostwo w obszarze walutowym o wspólnej walucie, wspólnym banku centralnym i wspólnej polityce monetarnej i fiskalnej będzie korzystne dla małych, otwartych gospodarek.

${ }^{38}$ R. I. McKinnon, Optimum Currency..., passim. 
Druga konkretyzacja (1): Członkostwo w obszarze walutowym o wspólnej walucie, wspólnym banku centralnym i wspólnej polityce monetarnej i fiskalnej będzie korzystne dla małych, otwartych gospodarek, charakteryzujących się mobilnością pracy pomiędzy nimi.

Twierdzenie faktualne (0): Członkostwo w obszarze walutowym o wspólnej walucie, wspólnym banku centralnym i wspólnej polityce monetarnej i fiskalnej będzie korzystne dla małych, otwartych gospodarek, charakteryzujacych się mobilnościa czynników wytwórczych pomiędzy nimi, tj. kapitału oraz w szczególności pracy.

Kenen, odnosząc się do modeli Mundella i McKinnona, opracował własny. W publikacji z 1969 r. wprowadził kolejne kryteria optymalności ${ }^{39}$. Stosując podejście metodologiczne Nowaka, można przyjąć następujący obraz struktury esencjalnej (S 3):

\section{Struktura 3}

$$
\begin{aligned}
& O^{U S_{F:}^{Z}} \text { (3) Fis } s^{40} \\
& \quad \text { (2) Fis, Dyw } \\
& \text { (1) Fis, Dyw, L } \\
& \text { (0) Fis, Dyw, L, K }
\end{aligned}
$$

$D y w$ - dywersyfikacja produkcji w gospodarce,

$(3), . .,(0)$ - poziomy istotności.

Na podstawie struktury esencjalnej (S 3) można sformułować prawo idealizacyjne (3.) o następującym brzmieniu: Członkostwo w obszarze walutowym o wspólnej polityce fiskalnej będzie korzystne dla gospodarek.

$\mathrm{W}$ toku rozumowania metodologii Nowaka i na podstawie struktury esencjalnej (S 3) pierwszą i drugą konkretyzację oraz twierdzenie faktualne można sformułować w następujacy sposób:

Pierwsza konkretyzacja (2.): Członkostwo w obszarze walutowym o wspólnej polityce fiskalnej będzie korzystne dla gospodarek charakteryzujących się zdywersyfikowaną produkcja.

Druga konkretyzacja (1.): Członkostwo w obszarze walutowym o wspólnej polityce fiskalnej będzie korzystne dla gospodarek charakteryzujących się zdywersyfikowana produkcjąi mobilnością pracy pomiędzy nimi.

Twierdzenie faktualne (0.): Członkostwo w obszarze walutowym o wspólnej polityce fiskalnej będzie korzystne dla gospodarek charakteryzujacych się zdywersyfikowana produkcją i mobilnością czynników wytwórczych pomiędzy nimi, tj. kapitału oraz w szczególności pracy.

$\mathrm{W}$ świetlej powyżej analizy trzech modeli zauważono istotne różnice w klasyfikacji kryteriów oraz ich doboru. W tabeli 1 porównano trzy struktury esencjalne (S 1, S 2 i S 3) reprezentujące każde z podejść i zbadano korespondencję pomiędzy nimi.

${ }^{39}$ Za: K. Sum, op. cit.; G. Tchorek, op. cit.; F. P. Mongelli, What is European Economic...; P. B. Kenen, op. cit.

${ }^{40} \mathrm{~W}$ literaturze przedmiotu często czynnik dywersyfikacji produkcji jest stawiany na pierwszym miejscu jako główny czynnik Kenena, jednak sam autor nadał im odwrotną istotność w: P. B. Kenen, op. cit., s. 150. Potwierdzili to również H. Dellas i G. Tavlas. 
Tabela 1

Porównanie obrazów struktury esencjalnej

\begin{tabular}{|c|l|l|l|c|}
\hline $\begin{array}{c}\text { Poziom } \\
\text { istotności }\end{array}$ & \multicolumn{1}{|c|}{ Mundell (S 1) } & \multicolumn{1}{|c|}{ McKinnon (S 2) } & Kenen (S 3) & Korespondencja \\
\hline 3 & L, E* & O, Uni, Fis & Fis & Brak \\
\hline 2 & L, K, E* & O, Uni, Fis, Reg & Fis, Dyw & Brak \\
\hline 1 & L, K, Reg, E* & O, Uni, Fis, Reg, L & Fis, Dyw, L & L \\
\hline 0 & L, K, Reg, Uni, E* & O, Uni, Fis, Reg, L, K & Fis, Dyw, L, K & L \\
\hline
\end{tabular}

Źródło: opracowanie własne.

Z zestawienia wyników analizy (tab. 1), stosując terminologię Nowaka, wynika, że korespondencja pomiędzy trzema omówionymi obrazami struktury esencjalnej (S 1, S 2 i S 3) jest znikoma. Główna debata pomiędzy omówionymi kluczowymi publikacjami dotyczącymi OOW odbywa się na poziomie czynników głównych (3. poziom istotności), gdzie nie występuje ani jeden czynnik wspólny, mimo że autorzy potwierdzaja, że współwystępowanie tych czynników jest istotne. Jedynym czynnikiem wspólnym dla wszystkich trzech struktur jest mobilność pracy $(L)$ (1. i 0. poziom istotności). Struktura 1 oraz Struktura 2 korespondują na najniższym poziomie istotności (0. poziom istotności) w zakresie czynników: mobilności pracy $(L)$, mobilności kapitału (K), założeniu, że gospodarki to regiony (Reg) oraz unifikacji monetarnej (Uni). Natomiast S 1 z S 3 koresponduje na najniższym poziomie (0. poziom istotności) w zakresie kryteriów mobilności pracy $(L)$ oraz mobilności kapitału $(K)$. Z kolei dla Struktury 2 i 3 czynnikami wspólnymi (0. poziom istotności) sa integracja fiskalna (Fis), mobilność pracy $(L)$ i mobilność kapitału $(K)$. Zatem modele wykazują większe podobieństwo, gdy analizowane sa w parach, ale mniejsze, gdy brane sa pod uwagę wszystkie trzy struktury. Największe podobieństwo na 0. poziomie istotności zauważa się przy porównaniu S 1 z S 2, zatem McKinnon wykazuje dość zbliżone stanowisko z Mundellem. Pomimo wyraźnych różnic w omawianych modelach (S 1, S 2 i S 3), w celu dalszej analizy w kolejnych podrozdziałach oraz na podstawie literatury przedmiotu dla potrzeb tej rozprawy sformułowano zbiorczy obraz struktury esencjalnej:

\section{Struktura 4}

$$
\begin{aligned}
& O^{U S_{F}^{Z}} \text { (3) } L, O, \text { Uni, Fis } \\
& \text { (2) } L, O, \text { Uni, Fis, Dyw } \\
& \text { (1) L, O, Uni, Fis, Dyw, K, Reg } \\
& \text { (0) L, O, Uni, Fis, Dyw, K, Reg, E }
\end{aligned}
$$

(3),..,(0) - poziomy istotności

$\mathrm{Na}$ ostatnim poziomie istotności (0.), tj. formułując twierdzenie faktualne, należałoby przyjąć wszystkie wymienione przez autorów kryteria. Tak więc 
powstały w ten sposób zestaw czynników ${ }^{41}$ składa się z: mobilności pracy $(L)$, otwartości gospodarki $(O)$, unifikacji monetarnej (Uni), integracji fiskalnej (Fis), dywersyfikacji produkcji i konsumpcji $(D y w)$, mobilności kapitału $(K)$, założeniu, że obszar walutowy zrzesza regiony $(R e g)$, elastyczności cen i płac $(E)$. Wymienione kryteria stanowiły punkt wyjścia dalszej debaty.

\section{PIERWSZA FAZA WERYFIKACJI TEORII}

Przedstawione w poprzedniej części modele OOW zapoczątkowały debatę teoretyczną i zaowocowały licznymi publikacjami ${ }^{42}$. W ślad za literaturą przedmiotu potwierdzono istotność wykazanych na początku czynników (S 4). Poza nimi wyróżniono także kolejne, jak:

a) podobieństwo stóp inflacji (Inf) - według Gottfrieda Haberlera ${ }^{43}$ oraz Johna Fleminga ${ }^{44}$, różnice $\mathrm{w}$ stopach inflacji krajów członkowskich moga zakłócić terms of trade i funkcjonowanie wspólnej polityki gospodarczej, w tym zapobiec występowaniu różnic w realnych stopach inflacji;

b) integrację rynków finansowych (Fin) - w literaturze przedmiotu za istotne kryterium optymalności, wskazane przez Jamesa Ingrama, uznaje się także warunek, który wynika z założeń definicji integracji walutowej ${ }^{45}$;

c) integrację polityczna $(P o l)$ - wymieniani przez literaturę przedmiotu Norman Mintz, Gottfried Haberler, Edward Tower i Thomas Willet zwracali uwagę, że więzi i zbliżone motywy polityczne zwiększą efektywność wspólnej polityki gospodarczej i zdolność do absorpcji wstrząsów oraz stanowią bardzo ważne kryterium optymalności ${ }^{46}$.

Należy zwrócić uwagę na fakt, że niektóre kryteria optymalności powinny zostać uwzględnione bądź nie, w zależności od przyjętej definicji obszaru walutowego. Według W. Maxa Cordena ${ }^{47}$ obszar walutowy to pseudounia monetarna (ang. pseudo-monetary union). Z kolei Tavlas ${ }^{48}$ wskazuje, że Corden pisał o pseu-

${ }^{41}$ Kryteria optymalności w myśl terminologii Nowaka to zestaw czynników głównych i pobocznych. W konsekwencji w niniejszym artykule określenie „kryterium optymalności” stosuje się zamiennie z określeniem „czynnik”.

${ }^{42} \mathrm{Za}$ : F. P. Mongelli, What is European Economic...; G. Tavlas, The "New" Theory of Optimum..., passim.

${ }^{43}$ Za: G. Tchorek, op. cit.

${ }^{44} \mathrm{Za}$ : F. P. Mongelli, What is European Economic...; G. Tavlas, The "New" Theory of Optimum..., passim.

${ }^{45}$ G. Tchorek, op. cit.; F. P. Mongelli What is European Economic...; idem, European Economic...; idem, "New" Views..., passim. Z kolei Tavlas, utożsamiając obszar walutowy z integracją walutowa, nie uwzględnia jednak tego kryterium, w: idem, The "New" Theory of Optimum..., passim.

${ }^{46}$ G. Tchorek, op. cit.; F. P. Mongelli, "New" Views...; G. Tavlas, The "New" Theory of Optimum..., passim.

${ }^{47}$ Za: P. B. Kenen, op. cit., s. 147.

${ }^{48}$ G. Tavlas, The "New" Theory of Optimum..., passim. 
dounii kursów walutowych (ang. pseudo-exchange rate union), która stanowi byt stojący o stopień niżej niż integracja monetarna. Jeżeli obszar walutowy byłby utożsamiany z definicją przyjętą przez Tavlasa, czyli z integracją monetarna, to integracja rynków finansowych wynika z samej definicji. Podobnie jeżeli uznać obszar walutowy za unię walutową ${ }^{49}$, kryterium jednego banku centralnego również rozumiane jest jako przyjęte ${ }^{50}$. W toku tego rozumowania także integracja polityczna stanowi kolejny krok ku unii politycznej jednego obszaru $^{51}$. Zatem z powyższego wynika, że teoria nie była spójna w zakresie definicji obszaru walutowego. W myśl metodologii idealizacji i konkretyzacji Nowaka, przy założeniu definicji, że obszar walutowy to unia monetarna, takie czynniki, jak integracja rynków finansowych (Fin) oraz unifikacja monetarna (Uni), należałoby uznać za już spełnione lub za czynniki główne ${ }^{52}$. Z kolei na znaczeniu moga zyskiwać pozostałe czynniki, tj. podobieństwo stóp inflacji (Inf), integracja fiskalna (Fis), elastyczność cen i płac $(E)$, mobilność pracy $(L)$, otwartość gospodarki $(O)$, mobilność kapitału $(K)$, dywersyfikacja produkcji i konsumpcji (Dyw), założenie, że obszar walutowy zrzesza regiony $(R e g)^{53}$.

W obszernej literaturze przedmiotu ${ }^{54}$, powstałej w odpowiedzi na publikacje Mundella, McKinnona i Kenena, wykazano także wiele dalszych niespójności i niejednoznaczności, które doprowadzały do różnych wniosków co do wyboru pomiędzy sztywnymi a płynnymi kursami walutowymi. Zwracano także uwagę na działanie kryteriów w krótkim, średnim albo długim okresie. Dellas i Tavlas ${ }^{55}$ wywnioskowali z analizy literatury przedmiotu powstałej w krótkim czasie po publikacji Mundella, McKinnona i Kenena, że paradygmat optymalnych obszarów walutowych nie był wówczas narzędziem do rozwiązywania konfliktów pomiędzy kryteriami optymalności. Pod koniec lat siedemdziesiątych analizę kryteriów optymalności przeprowadzano w sposób bardziej kompleksowy ${ }^{56}$.

Wielu badaczy podważało możliwość klasyfikacji kryteriów względem poziomu ich istotności ${ }^{57}$. Mongelli ${ }^{58}$ kreśli pewne uwagi, które można by przedstawić w następującym obrazie struktury esencjalnej (S 5):

\footnotetext{
${ }^{49} \mathrm{Na}$ różnicę pomiędzy unią walutową a monetarną zwrócił również uwagę T. W. Kolasiński, op. cit.

${ }^{50}$ J. Priewe, op. cit., wyróżnia aż 5 typów, które mogłyby być utożsamiane z obszarem walutowym, z kolei M. Jurek, op. cit., podkreśla, że głównym problem z punktu widzenia metodologii jest brak wspólnej definicji obszaru walutowego.

${ }^{51}$ Należy wziąc pod uwagę, że integracja polityczna jest tak naprawdę wieloetapowym procesem przebiegającym równolegle z postępem ogólnej integracji Unii Europejskiej.

${ }^{52} \mathrm{Z}$ drugiej jednak strony można by je również uznać za ślepe, skoro oba czynniki już występują w analizowanym zakresie (Z), czyli zbiorze gospodarek.

${ }^{53}$ Zob. struktura esencjalna S 4.

${ }^{54}$ H. Dellas, G. Tavlas, op cit.; G. Tavlas, The Theory of Monetary Integration, Kluwer Academic Publishers, „Open Economies Review” 5, 1994.

${ }^{55}$ H. Dellas, G. Tavlas, op. cit., s. 25.

${ }^{56}$ Y. Ishiyama, op. cit.

${ }^{57}$ G. Tchorek, op. cit.; G. Tavlas, The Theory of Monetary..., passim.

${ }^{58}$ F. P. Mongelli, "New" Views..., passim.
} 


\section{Struktura 5}

$$
\begin{aligned}
& O^{U S_{F:}^{Z}} \text { (3) } L, E, \text { Pol } \\
& \text { (2) } L, E, \text { Pol, Fin } \\
& \text { (1) L, E, Pol, Fin, Inf, K } \\
& \text { (0) L, E, Pol, Fin, Inf, K, O, Dyw }
\end{aligned}
$$

$(3), . .,(0)$ - poziomy istotności

W strukturze esencjalnej (S 5) zestawionej na potrzeby tego opracowania nie uwzględnia się integracji fiskalnej (Fis), unifikacji monetarnej (Uni) ani definicji obszaru walutowego jako zbioru regionów (Reg) - czynników, które były w sposób wyraźny zaznaczone jako bardzo istotne dla twórców TOOW. Redukuje się poziom istotności otwartości gospodarki $(O)$ z trzeciego na zerowy oraz dywersyfikacji produkcji $(D y w)$ z drugiego na zerowy. Zatem S 5 zestawiona z S 4 nie tworzy bazowej korespondencji, tylko pochodna, co na tym etapie tworzenia się TOOW potwierdza założenie metodologii Nowaka o walce orientacji teoretycznych ${ }^{59}$.

\section{DRUGA FALA USTRUKTURYZOWANIA PIERWOTNYCH ZAŁOŻEŃ}

Nazwana przez Mongellego ${ }^{60}$ faza pogodzenia ${ }^{61}$ to czas, kiedy wprowadzono nowe metakryterium optymalności, tj. podobieństwo wstrząsów (ang. similarity in/of shocks). Niemniej jednak w tej rozprawie uznaje się, że jest to podobieństwo reakcji na wstrząsy $(S z)$. McKinnon poparł Mundella ${ }^{62}$, uznając, że to podobieństwo nie stanowi warunku wstępnego, o ile występuje integracja rynków finansowych (Fin).

Badacze, którzy podjęli próbę klasyfikacji kryteriów optymalności ${ }^{63}$, podkreślali ponadto istotność elastyczności cen i płac $(E)$, podobieństwa stóp inflacji (Inf), otwartości gospodarki $(O)$, definicji obszaru jako zbioru regionów (Reg) oraz redukowali znaczenie fiskalnej integracji $(F i s)^{64}$ i mobilności czynników wytwórczych $(K \text { i } L)^{65}$.

\footnotetext{
${ }^{59}$ L. Nowak, op. cit., s. 201.

60 F. P. Mongelli, "New” Views..., passim.

61 Ang. reconciliation phase.

${ }^{62}$ Za: F. P. Mongelli, What is European Economic..., passim.

${ }^{63}$ Por. E. Tower, T. D. Willet, The Optimum Currency Areas and Exchange Rate Flexibility,
} Princeton, N.J. International Finance Section, Dept. of Economics, Princeton University, 1976; Y. Ishiyama, op. cit.

${ }^{64}$ Polityka fiskalna, która jest elastyczna, powinna być odpowiednim narzędziem pozwalającym na zastosowanie polityki absorpcji wydatków (ang. expenditure absorption policy) dla danego kraju według Cordena, co w niniejszym artykule uznaje się, że implikuje konieczna samodzielną politykę fiskalna, a zatem obniżenie poziomu istotności integracji fiskalnej. F. P. Mongelli, New"Views..., passim.

${ }^{65}$ F. P. Mongelli, New”Views..., passim. 
Zatem nowy obraz struktury esencjalnej, uwzględniajacy te modyfikacje, można zaprezentować następująco (S 6):

\section{Struktura 6}

$$
\begin{aligned}
& O^{U S_{F}^{Z}} \text { (3) } E, \text { Inf } \\
& \text { (2) E, Inf, Fin, Sz } \\
& \text { (1) E, Inf, Fin, Sz, O, Reg, K } \\
& \text { (0) E, Inf, Fin, Sz, O, Reg, K, L, Fis, Dyw, Pol*66 }
\end{aligned}
$$

(3),..,(0) - poziomy istotności

W zaprezentowanej strukturze esencjalnej (S 6) odnotować można zmianę w doborze kryteriów optymalności w porównaniu ze strukturą esencjalną (S 5). Na wysokim poziomie istotności (2.) uwzględniono nowe kryterium podobieństwa reakcji na wstrzasy $(S z)$. Z kolei integracja polityczna $(P o l)$ nie została dodana do zestawienia, zatem uznaje się ją za czynnik ślepy w myśl metodologii Nowaka.

W świetlej powyższej analizy trzech modeli (S 4, S 5 i S 6) reprezentujących kolejne fazy ewolucji stanowisk teoretycznych można stwierdzić istotne różnice w klasyfikacji kryteriów oraz ich doboru. W tabeli 2 porównano trzy struktury esencjonalne reprezentujące każde z ujęć.

Tabela 2

Porównanie obrazów w ramach faz stanowisk teoretycznych

\begin{tabular}{|c|l|l|l|c|}
\hline $\begin{array}{c}\text { Poziom } \\
\text { istotności }\end{array}$ & $\begin{array}{c}\text { TOOW twórców } \\
\text { (S 4) }\end{array}$ & \multicolumn{1}{|c|}{ Faza 1 (S 5) } & \multicolumn{1}{|c|}{ Faza 2 (S 6) } & Korespondencja \\
\hline 3 & L, O, Uni, Fis & L, E, Pol & E, Inf & Brak \\
\hline 2 & $\begin{array}{l}\text { L, O, Uni, Fis, } \\
\text { Dyw }\end{array}$ & L, E, Pol, Fin & E, Inf, Fin, Sz & Brak \\
\hline 1 & $\begin{array}{l}\text { L, O, Uni, Fis, } \\
\text { Dyw, K, Reg }\end{array}$ & $\begin{array}{l}\text { L, E, Pol, Fin, } \\
\text { Inf, K }\end{array}$ & $\begin{array}{l}\text { E, Inf, Fin, Sz, O, } \\
\text { Reg, K }\end{array}$ & K \\
\hline 0 & $\begin{array}{l}\text { L, O, Uni, Fis, } \\
\text { Dyw, K, Reg, E }\end{array}$ & $\begin{array}{l}\text { L, E, Pol, Fin, } \\
\text { Inf, K, O, Dyw }\end{array}$ & $\begin{array}{l}\text { E, Inf, Fin, Sz, } \\
\text { O, Reg, K, L, Fis, } \\
\text { Dyw, Pol* }\end{array}$ & L, O, Dyw, K, E \\
\hline
\end{tabular}

Źródło: opracowanie własne.

Jak wynika z tabeli 2, na najniższym poziomie istotności (0) obrazy uwzględniają więcej wspólnych czynników w porównaniu z tabelą 1. Niemniej nadal nie został osiagnięty próg dojrzałości nauki w rozumieniu koncepcji Nowaka ${ }^{67}$. Nie występuje jeszcze korespondencja bazowa, tj. na poziomie

\footnotetext{
66 Dla celów porównań przyjmuje się dla wszystkich obrazów 4 poziomy istotności,

${ }^{67}$ L. Nowak, op. cit., s. 195.
} 
czynników głównych (3). Z zestawienia w tabeli 2 wynika, że teoria pod wpływem kolejnych publikacji nabiera pewnych ram, ale nadal nie jest podparta badaniami empirycznymi. Ponadto zauważa się brak uwzględnienia czynnika unifikacji monetarnej (Uni), zatem można wnioskować, że w ujęciu porównywanych koncepcji obszar walutowy to unia monetarna z bankiem centralnym. Z drugiej strony podkreśla się rolę integracji rynków finansowych (Fin), co w obrębie pierwszych modeli Mundella, McKinnona czy Kenena powinno być uwzględnione ze względu na przyjętą definicję obszaru walutowego.

W rezultacie otwarta kwestią pozostaje nadal kwestia niespójności definicji obszaru walutowego. Problem można wyjaśnić tym, że unifikacja monetarna (Uni), integracja rynków finansowych (Fin), a także integracja polityczna (Pol) to czynniki, które ewoluują w czasie i są etapowymi procesami. Zatem z jednej strony powinny być zawsze wymieniane jako czynniki główne, ponieważ ich obecność jest niezbędna, ale stopień ich wpływu może się zmieniać w czasie i różnie oddziaływać na optymalność obszaru walutowego. Stąd płynie wniosek, że do wybranych kryteriów optymalności należy się odnosić nie jak do warunków wstępnych, ale do czynników, których wpływ dopiero w średnim lub długim okresie nabiera znaczenia. Wówczas obraz struktury esencjalnej optymalności obszaru walutowego różniłby się w zależności od czasowej perspektywy jej postrzegania. Na czasowe działanie niektórych czynników zwracali też uwagę tacy autorzy, jak Grzegorz Tchorek ${ }^{68}$, Francesco Mongelli69, Tanya Broz ${ }^{70}$, George Tavlas ${ }^{71}$ oraz European Commission ${ }^{72}$. Nowa teoria optymalnych obszarów walutowych potwierdziła te założenia.

\section{PODSUMOWANIE}

Zestaw warunków i cech, które kraje uczestniczące w obszarze walutowym powinny spełniać, aby czerpać korzyści z członkostwa, ewoluował. Metoda idealizacji i konkretyzacji Nowaka posłużyła jako przydatne narzędzie w celu wykazania czynników istotnych dla optymalności obszaru walutowego oraz podziału ich na czynniki główne i poboczne. W rezultacie wykazano klarowny zestaw czynników istotnych dla optymalności obszaru walutowego, tożsamy z obrazem struktury esencjalnej S 6. Niemniej jednak klasyfikacja wybranych kryteriów optymalności była utrudniona przez niespójną terminologię w literaturze przedmiotu.

Słabością TOOW jest definicja obszaru walutowego - czy jest ona traktowana jako integracja monetarna czy unia monetarna, gdyż w zależności od definicji powinien być przyjmowany jako istotny odmienny zestaw kryteriów

68 G. Tchorek, op. cit.

${ }^{69}$ F. P. Mongelli, New" Views on the optimum...; idem, What is European Economic...; idem, European Economic and Monetary Integration..., passim.

${ }^{70}$ T. Broz, The Theory of Optimum Currency Areas: A Literature Review, „Privredna Kretanja i Ekonomska Politika" 104/2005.

${ }^{71}$ G. Tavlas, The "New" Theory of Optimum..., passim.

72 European Commision, One market, One Money..., passim. 
optymalności. Klasyfikacja czynników w zależności od definicji obszaru walutowego byłaby także odmienna.

Tradycyjna teoria optymalnych obszarów walutowych nie jest teorią dojrzała w rozumieniu Nowaka ze względu na brak korespondencji na poziomie czynników głównych, tj. najistotniejszych kryteriów optymalności.

Kolejnym wnioskiem $\mathrm{z}$ analizy jest fakt, że wybrane spośród istotnych kryteria optymalności to długotrwałe procesy, tj. integracja finansowa (Fin), integracja polityczna $(\mathrm{Pol})$, integracja fiskalna (Fis), unifikacja monetarna (Uni), które są kluczowe w długim okresie do prawidłowego funkcjonowania optymalnego obszaru walutowego. Nie wyklucza to jednak stwierdzenia, że pozostałe kryteria to również długotrwałe procesy. Niemniej jednak te kryteria, które wspomniano powyżej, stanowiły najczęściej przedmiot debaty w literaturze przedmiotu. Stąd obraz struktury esencjalnej będzie odmienny w zależności od czasowej perspektywy jej postrzegania.

Wykazany w tym artykule obraz struktury esencjalnej (S 6) pozwala na określenie istotnych dla optymalności obszaru walutowego czynników, pod warunkiem że jasno zdefiniowane zostanie pojęcie obszaru walutowego. Ponadto zaprezentowana klasyfikacja może być różna w zależności od czasowej perspektywy jej postrzegania. Należy także zaznaczyć, że istotność wybranych kryteriów optymalności może być różna dla poszczególnych gospodarek ze względu na ich strukturalne uwarunkowania.

mgr Magdalena Kobla-Ziętek

Uniwersytet Ekonomiczny w Poznaniu

magdalena.kobla@gmail.com

TRADITIONAL THEORY OF OPTIMAL CURRENCY AREAS (OCA)

Sum mary

The paper stands out because of the use of a specific methodology. The aim of this paper is to present and assess the evolution of the old theory of the Optimal Currency Areas (OCA) using the methodological concept of idealisation and substantiation developed by L. Nowak. A special attention has been given to optimum criteria. A historical comparative analysis method used together with the idealisation and substantiation concept enabled identification of the aims, and the main as well as side factors in all OCA models. The paper is divided in 6 parts: Introduction, Methodological Introduction, three main parts and Conclusion. In the methodological part the author offered the rationale for the use of the idealisation and substantiation concept. The following parts contain a collection of basic theoretical assumptions of the OCA. Parts four and five contain an assessment of two time periods which represented different attitudes towards the basic theoretical assumptions. In all parts, separate OCA models have been verified using the idealisation and substantiation method. 
Copyright of Journal of Law, Economics and Sociology is the property of Faculty of Law and Administration of Adam Mickiewicz University in Poznan and its content may not be copied or emailed to multiple sites or posted to a listserv without the copyright holder's express written permission. However, users may print, download, or email articles for individual use.

Właścicielem praw autorskich do „Ruchu Prawniczego, Ekonomicznego i Socjologicznego” jest Wydział Prawa i Administracji Uniwersytetu im. Adama Mickiewicza w Poznaniu. Zawartość czasopisma nie może być kopiowana, przesyłana do innych stron internetowych bądź zamieszczana na blogach bez pisemnej zgody wydawcy. Niemniej artykuły można drukować, kopiować lub przesyłać w formie elektronicznej na własny użytek. 